\title{
The Olympic Volunteer and Olympic Education: Suggestions for Administrators of Olympic Games
}

\author{
George Karlis, Ph.D. \\ Full Professor | School of Human Kinetics | University of Ottawa/Canada \\ gkarlis@uottawa.ca
}

\section{Introduction}

The Olympic Games have become the largest mega sport events in modern times. This growth has posed a number of challenges for host administrators of Olympic Committees such as safety and security, facilities and accomdation, as well as volunteer services. As Olympic Games have increased in size, the reliance of volunteers for service provision has also increased. Recent Summer Olympic Games have relied on the services of over 60,000 volunteers. To ascertain that the services provided by volunteers are sufficient, volunteers should possess a knowledge base of Olympic Education. Administrators of Olympic Games will have to incorporate certain administrative practices in their recruitment and training of volunteers to make sure that volunteers have a knowledge base of Olympic education. The purpose of this paper is to describe how Olympic education may be of use to the Olympic Games Volunteers and be of relevance to enhancing the quality of service provided by volunteers. The objective of this paper is to present suggestions for administrators of Olympic Games as to how Olympic education can be implemented in the recruiting and training process used to prepare volunteers for the provision of services at upcoming games. To fulfill the objective of this paper, the main body is divided into three parts:

(1) volunteerism at the Olympic Games, (2) Olympic education and Olympic volunteerism, and (3) suggestions for administrators of Olympic Games. The paper concludes with the following five suggestions for administrators of Olympic Games: (1) offer Olympic education courses outside of the regular training sessions provided to volunteers, (2) offer/expand Olympic education sessions integrated into the regular volunteer training sessions, (3) encourage volunteers to self-educate themselves on Olympism and the Olympic Movement, (4) publish a bi-weekly newsletter for volunteers focusing on 
Olympism and the Olympic Movement, and (5) make a "basic knowledge of the ideals of the Olympic Games" a prerequisite for applying for volunteer positions.

Pierre de Coubertin founded the modern day Olympics in 1896, and since the formation of the International Olympic Committee (IOC) in 1894, administrators working on behalf of the IOC have strived to make the Olympic Games and the Olympic movement a global success. Not only have the games grown in size and structure since 1896, the reliance of the provision of services from volunteers since 1980 has also increased.

This high reliance on volunteers has increased the demand for quality training of volunteers. The question that needs to be asked is how well qualified are volunteers in making the Olympic Games a success? To enhance the probability of providing a competent volunteer service, Olympic Games Volunteers go through a training process, yet how much, if any of this process is devoted to Olympic education? Without doubt, Olympic Games volunteers would be better qualified to provide a service of the Olympic Games if their comprehension level of the Olympic Games, the ideals of the Olympic Games, and the philosophy of the Olympic Games is at a high level.

\section{Volunteerism at the Olympic Games}

The Olympic Volunteer was first officially defined as "a person who makes an individual, altruistic commitment to collaborate, to the best of his/her abilities in the organization of the Olympic Games, carrying out the tasks assigned to him/her without receiving payment or rewards of any other nature (Memoria Oficial de los Juegos Olimpicos de Barcelona, 1992: 381).The Olympic volunteer is still quite a new trend (Karlis 2006; Belen Moreno, de Moragas, and Paniagua, 1999). Although volunteers were used by the Olympic Games prior to 1980, the Lake Placid Games are credited as being the first to kick-start the volunteer movement of the Olympic Games. The trend that commenced at Lake Placid has continued to date as the reliance on volunteers for the implementation of the services of the events has continued to grow. The most recent summer games held in London in 2012 utilized 70,000 Olympic Volunteers whereas the most recent winter games in Vancouver depended on the help of 18,500 volunteers (see Table 1). 


$\begin{array}{llll}\begin{array}{l}\text { Summer } \\ \text { Games }\end{array} & \begin{array}{l}\text { No. of } \\ \text { volunteers }\end{array} & \begin{array}{l}\text { Winter } \\ \text { Games }\end{array} & \begin{array}{l}\text { No. of } \\ \text { volunteers }\end{array} \\ \text { Los Angeles 1984 } & 28,742 & \text { Lake Placid 1980 } & 6,703 \\ \text { Seoul 1988 } & 27,221 & \text { Sarajevo 1984 } & 10,450 \\ \text { Barcelona 1992 } & 34,528 & \text { Calgary 1988 } & 9,498 \\ \text { Atlanta 1996 } & 60,422 & \text { Albertville 1992 } & \text { not available } \\ \text { Sydney 2000 } & 47,000 & \text { Lillehammer 1994 } & 9,054 \\ \text { Athens 2004 } & 65,000 & \text { Nagano 1998 } & 32,579 \\ \text { Beijing 2008 } & 100,000 & \text { Salt Lake City 2002 } & 19,000 \\ \text { London 2012 } & 70,000 & \text { Torino 2006 } & 20,000 \\ & & \text { Vancouver 2010 } & 18,500\end{array}$

Tab. 1: The Number of Olympic Volunteers at the Summer and Winter Olympic Source: Author's diagram

The 2012 London Olympic Games marked the 32nd year since the implementation of the volunteer movement of the Olympic Games. The Olympic Games (both summer and winter) of the past 32 years have relied on similar principles and practices for the recruiting, training and implementation of volunteer services. Volunteers tend to be recruited from within the host city and host nation (Karlis 2006). This of course makes practical sense from the perspective that volunteers take time of work, are unpaid, and cover their own expenses throughout the volunteer experience (Karlis 2004; 2003). Since host cities and nations depend in large part on volunteers from within their respective society, recruitment efforts have also been aided by the government of host nations. For example, in the case of the Sydney 2000 Olympics, the recruitment of volunteers from Australia was assisted by Clause 93 of the Public Sector Management (General) Regulation of 1996 allowing employees a maximum of five days work leave for volunteer work at the Olympic Games (Premiers Department-New South Wales, 1998).

Recruitment of volunteers for the Olympic Games is a long process that begins with planning once the host city has been awarded the games. During the four year period following the completion of the previous games, the host nation implements the planning and recruitment process of volunteers. 
Roughly one year prior to the commencement of the games the period for applying for volunteer positions is closed. From that point on, the actual volunteers are selected from the pool of candidates that applied. An important criteria for volunteer selection is being able to communicate in the host language, English, and French which is the official language of the modern day Olympiad. In the case of Sochi for example, March 1, 2013 marked the closing date for receiving volunteer applications - over 180,000 applications were received. As is typically the case, most applicants were from the host nation, which means Russia for the upcoming Olympic Winter Games in Sochi (Russia). From these applicants, 25,000 will be selected to serve as volunteers for these games that commence February 7, 2014 (Volunteers Sochi. http://vol.sochi2014.com/en/).

As is the case with recruitment, the training of Olympic Volunteers is undertaken through the auspices of the National Olympic Committee of the host nation. The training practices of volunteers that have traditional been employed by the National Olympic Committees tend to consist of three general categories: (1) orientation training, (2) venue training, and (3) task specific training. The orientation training sessions focus on getting volunteers accustomed to the assignment at hand. The emphasis of the orientation training session is on learning about the Olympic spirit, acquiring knowledge of the host Olympic city, picking-up skills of customer service, introducing codes of conduct and a depiction of the job description of the volunteer.

Venue training focuses on passing on information of the infrastructure, location, and space of the Games facilities, services, and buildings. The objective of venue training expands beyond getting to know the sites to comprehending the role of each venue. The objective of venue training also incorporates an explanation of the policies and procedures for the services of health, safety, well-being, and emergency.

Task specific training entails the passing on of knowledge paramount to accomplishing a specific work task. Task specific training is case specific depending on the type of assignment. Those who work as ushers at specific venues, for example, are provided with a detailed overview of their specific job description in relation to others that are working in a similar capacity. Whereas, those who work as National Olympic Committee Assistants of Chef $d u$ Missions of participating countries partake in detailed task specific 
training sessions that include everything from cultural education to task assignments.

In the case of Athens, the organizing committee of Athens 2004 incorporated the example of previous Olympic Games for putting together a volunteer policy. Specifically, the Athens organizing committee incorporated the following approach for the recruitment and management of volunteers: "(1) the selection of volunteers based on merit, (2) a personal interview followed by training, (3) the people and their diversity were valued, (4) working in partnerships was promoted, and (5) open and communicative methods were used" (Karkatsoulis, Michalopoulos and Moustakatou 2005: 587).

The training practices for Olympic Volunteers have become more important than ever. In London, volunteers were coined Game Makers for a reason. This term implied that the success of the games really did depend on their performance during the games which stemmed from their preparation prior to the games. One of the current challenges of volunteerism at mega-sport events such as the Olympics stems from information technologies and languages (Belen Moreno, de Moragas, and Paniagua 1999). The use of computers and electronic communication systems has become a necessary skill for current day volunteers. Language and communication training has also come to the forefront in importance as the Olympics attract a global audience that communicates differently both verbally and expressively. Volunteers are called upon to be able to comprehend verbal and non-verbal communications such as expressions and gestures while being able to respond in ways that are not offensive to visitors of the Games. The Sydney organizing committee was one of the first to identify this changing need and subsequently relied on university Faculties of Communication Sciences to best address this concern (Belen Moreno, de Moragas, and Paniagua 1999).

Language and communication skills are an asset for those who have been recruited and selected to serve as Olympic Volunteers. Indeed those who are selected to be Olympics Volunteers tend to be come from various age groups, tend to be educated at the post secondary level, and tend to be economically comfortable. This is articulated in research by Georgiadis, Spiliopoulos, Rampotas, and Rampotas (2006) indicating that of the 430 Olympic volunteers surveyed from the Athens Olympic Games, most were 
male, had university education, were single, were between the ages of 16 to 45 , had a paid job, and were in good financial status

\section{Olympic education and Olympic Volunteerism}

When de Coubertin initiated the establishment of the International Olympic Committee in 1894, his intent was to extend beyond the implementation of the games to the promotion of sport through education, and, the promotion of education through sport. In fact, de Coubertin's main objective of the Olympic Games was educational as the Olympic Games "were to be seen as an advertisement of sport to youth, and the athletes participating in the Olympic Games seen as role models for a younger generation" (Girginov and Parry, 2005: 216).

Today the education mission of the Olympic Movement focuses on disseminating knowledge pertaining to the Olympic Games, and, in particularly, promoting the spirit of sport and athleticism to the younger generation. Specifically, there are four main objectives of the education mission of the Olympic Movement: "(1) to foster interest in the Olympic Games and in the aims and ideals of the Olympic Movement, with particular reference to young people; (2) to provide the study and application of the education and social principles of the Olympic Movement; (3) to contribute to the diffusion of Olympism in the teaching programmes of physical education and sport in schools and universities; and, (4) to help create institutions which devote themselves to Olympic education (such as the International Olympic Academy in Ancient Olympia and National Olympic Academies) (Girginov and Parry, 2005: 222). A big part of the mandate of the education mission of the Olympic Movement is carried out by the International Olympic Academy (IOA) located in Ancient Olympia, Greece. According to Filaretos (1987), the intent of the International Olympic Academy focuses on the study of the educational ideals of the Olympic Games. That is, the International Olympic Academy acts as a meeting place for the exchange, dissemination, and application of knowledge pertaining to the Olympic Games. Specifically, the functions of the International Olympic Academy include: (1) a yearly international post-graduate seminar, (2) a yearly International Olympic Academy International Session, (3) educational session for sport groups or associations (i.e., sport media, sport officials) that focus on the Olympics, and (4) 
hospitality for educational study-focused groups from universities, colleges, and other institutes of higher learning (Girginov and Parry, 2005).

In addition to the International Olympic Academy, the National Olympic Committees also have a mandate for Olympic education. Although each National Olympic Committee differs, the International Olympic Committee has taken action to ascertain that each National Olympic Committee moves toward the promotion and implementation of Olympic education. In its Olympic Charter (2003: 44), the International Olympic Committee states that: "NOC's (National Olympic Committees) have a mission to develop and protect the Olympic Movement ... and otherwise contribute, among other things, to the diffusion of Olympism in the teaching programmes of physical education and sport in schools and university establishments...[to] see to the creation of institutions which devote themselves to Olympic education."

As stated in the Olympic Charter, the primary emphasis of the National Olympic Committees has been on spreading Olympic education through the school systems. Focus has been placed primarily on integrating Olympic education into curricula, particularly physical education programs, or other related teaching programs in order to promote the ideal, values and philosophies of Olympism and sport (Siedentop 1994). As a result, those who volunteer at the Olympic Games need to have been apart of these aforementioned programs or at the very least, have self-educated themselves on Olympism, in order to possess a body of knowledge of the Olympic movement. Although no known research has been conducted on the comprehension level of Olympism of past Olympic Games volunteers, it is most likely that most Olympic Volunteers of the past did not have any formal education on Olympism. In 1999, at the International Symposium on Volunteers, Global Society and the Olympic Movement held jointly by the International Olympic Committee and the Olympic Studies Centre of the Autonomous University of Barcelona, the issue of Olympic education for Olympic volunteers was addressed. Specifically, it was proposed at this symposium that Olympic leaders take the lead in establishing Olympic education programs for volunteers. It was also proposed that "the phenomenon of volunteer service be clearly integrated into Olympic education programmes as an example of the commitment of the Olympic Movement to the values of solidarity, peace, equality, and participation that are characteristic of the 
volunteer movement in general" (IOC: Documents and Museums Collection, 2000: 3).

\section{Suggestions for Administrators of the Olympic Games}

From the aforementioned it may be assumed that the level of Olympic education possessed by Olympic Volunteers, in general, may not be as high as it should be. Should a volunteer, just like a paid employee, not have a good general knowledge of the culture and history of the organization that she/he is a part of? Volunteers would thus benefit not only themselves, but also those they serve, if they indeed possess a sufficient knowledge of Oympism. To ascertain that volunteers possess this knowledge of Olympism, the following suggestions have been established for administrators of Olympic Games.

Suggestion 1: Offer Olympic education courses outside of the regular training sessions provided to volunteers.

To make certain that Olympic Volunteers comprehend the history, nature and focus of the Olympic Games, administrators of Olympics Games would be wise to offer mandatory courses outside of the regular training sessions provided to volunteers on: (1) the history of the ancient Olympic Games, (2) the history of the modern Olympic Games, (3) the activities and events of the Olympic Games, (4) the nature of Olympism, and (5) the philosophy behind the Olympic Games. These courses should each provide a minimum of ten hours of class time and should be completed by the prospective volunteer prior to commencing the volunteer training session.

Suggestion 2: Offer/expand Olympic education sessions integrated into the regular volunteer training sessions. Typically, some, if not all of the training sessions provided to Olympic Volunteers include a brief introduction of the Olympic Games. This however is not enough to expand the knowledge base of volunteers. As a start, all training sessions for all volunteer positions should include a general course on Olympic education. This general course should provide an overview of the Olympic Movement from start to finish. Administrators of Olympic Games should consider commencing all volunteer training sessions with a general course on Olympic education. This will ensure that all volunteers will possess, at minimal, a basic knowledge of the Olympic Games and its ideals. 
Suggestion 3: Encourage volunteers to self-educate themselves on Olympism and the Olympic Movement.

As soon as an applicant is made an offer of volunteer employment at the Olympic Games, she/he should be encouraged to learn about Olympism and the Olympic Movement. The "letter of offer" sent to volunteers should emphasize the importance of proper Olympic education to assure success in the volunteer experience while also pinpoint avenues to help one become "self-educated" on the Olympics. A list of suggested readings and pertinent web sites should be attached to this "letter of offer" to open the door for the prospective volunteer to become self-educated on Olympism and the Olympic Movement.

Suggestion 4: Publish a bi-weekly newsletter for volunteers focusing on Olympism and the Olympic Movement.

This bi-weekly newsletter should be targeted directly to volunteers and should have as its mission the dissemination of a broad array of knowledge on all aspects (from planning to administration) of the Olympic Games. The intent of this bi-weekly newsletter should be to keep volunteers regularly informed of the preparations leading up to the Olympic Games including an overview as to how these Olympic Games will accomplish the ideals of Olympism. The publishing of this newsletter should come from the National Olympic Committee of the host nation in collaboration with the IOC. This initial newsletter should be mailed, or e-mailed to volunteers with the "letter of offer." This will make certain that the process of Olympic education commences as soon as possible.

Suggestion 5: Make a "basic knowledge of the ideals of the Olympic Games" a prerequisite for applying for volunteer positions. The list of prerequisites required for volunteer positions should include a basic knowledge of the ideals of the Olympic Games so that volunteers, at the very least, recognize that this is an important requirement for successfully accepting this responsibility. Administrators of Olympic Games would benefit from asking a series of questions on the volunteer application form to evaluate the comprehension level of the Olympic Games of applicants. By asking these questions, not only will administrators depict which applicants have a basic knowledge of the Olympic ideals, prospective applicants will also be en- 
couraged to learn more about the Olympic ideals through self-generated research prior to completing the volunteer application form.

\section{Conclusions}

At the International Symposium on Volunteers, Global Society and the Olympic Movement held in 1999 it was concluded that: "The contribution of volunteers does not therefore stop at the provision of services and the performance of tasks; it extends to the creation of cultural and social conditions that are essential today for the celebration of the Games" (IOC: Documents and Museums Collection, 2000: 1). This statement justifies the need for Olympic Games volunteers to possess an adequate level of Olympic education. By implementing the aforementioned suggestions, the knowledge level of Olympic ideals of volunteers will be enhanced thus aiding in the role volunteers will play in the creation of the cultural and social conditions essential for the success of the Olympic Games. The suggestions made in this paper for administrators of Olympic Games may be used as a guide by the National Olympic Committee for educating volunteers on Olympism and the Olympic Movement. After all, volunteers are "front-line" employees of the games. Initial contact of spectators of the games and visitors to host cities will more than likely take place with volunteers. If volunteers are well prepared and knowledged on the ideals of the Olympics, they will be in a better position to not only serve but also provide a quality service thus enhancing the spectator and visitor experience of the Olympic Games.

Olympic education as a part of the training process may help make the experience of volunteering more meaningful for volunteers. Those who decide to volunteer, including those who decide to become Olympic Volunteers tend to be motivated by a number of factors. According to Belen Moreno, de Moragas, and Paniagua (1999), a number of motivation factors, in addition to the actual impact they may have on the games, are identified as being common of Olympic Games Volunteers. These are: "(1) the spirit of solidarity and peace enshrined in the Olympic philosophy, (2) commitment as citizens, members of an association or nation, (3) individual challenge, (4) belonging to a group, (5) identification as a member of that group, and (6) the various forms of individual gratification" (Belen Moreno, de Moragas, and Paniagua, 1999: 10). Similarly, Georgiadis, Spiliopoulos, Rampotas, and Rampotas (2006) identified values, knowledge, personal development, elevation of self-confidence, and interest for community as motives for volun- 
teering at the Olympics. Administrators responsible for implementing Olympic education through training would be wise to take into consideration these motivational factors.

Keywords: Olympic Volunteer, Olympic education, Olympic Games, Recruitment and Training of Volunteers

Schlagwörter: Olympische Freiwillige, Bildung, Olympische Spiele, Anwerbung und Training von Freiwilligen.

\section{Bibliography}

Belen Moreno, Anna., de Moragas, Miguel. and Paniagua, Raul (1999): The evolution of volunteers at Olympic Games, Paper presented at the Olympic Movement Conference, Lausanne, November 24-26.

Filaretos, Nikos. (1987): The International Olympic Academy, proceedings of the $27^{\text {th }}$ Session of the Olympic Academy, p. 27-31.

Georgiadis, Thanos, Spiliopoulos, Panagiotis. Rampotas, Christos. and Rampotas, George. (2006): Motivation and volunteer participation in the "Athens 2004" Olympic Games, in: ChoregiaSport Management International Journal, Volume 2, Issues 1-2, p. 65-89.

Girginov, Vassil, and Parry, Jim. (2005): The Olympic Games Explained: A Student Guide to the Evolution of the Modern Olympic Games, London.

International Olympic Committee (2003): The Olympic Charter, Lausanne, International Olympic Committee.

International Olympic Committee (Documents in the Museum Collection) (2000): Conclusion and Recommendations: International Symposium on Volunteers, Global Society and the Olympic Movement, November 1999, Autonomous University of Barcelona, Spain.

Karlis, George. (2003): Volunteerism and multiculturalism: A linkage for future Olympics. The Sport Journal, Volume 6, Issue 3, p. 1-16.

Karlis, George. (2004): Leisure and Recreation in Canadian Society, Toronto.

Karlis, George. (2006): Assessing the needs of "sport volunteer tourists" at the Olympic Games: Implications for administrators of mega sport events, Keynote Address: The $14^{\text {th }}$ European Association for Sport Management Congress, Nicosia, Cyprus, September 9.

Karkatsoulis, Panos., Michalopoulos, Nikos., and Moustakatou, Vasso. (2005): The national identity as a motivational factor for better performance in the public sector: The case of the volunteers of the Athens 2004 Olympic Games, in: International Journal of Productivity and Performance Management, Volume 54, Issue 7, p. 579-594.

Memoria Oficial de los Juegos Olimpicos de Barcelona (1992): Barcelona: COOB'92.

Premiers Department, New South Wales. (1998). Role of the New South Wales Public Sector in the 2000 Olympic and Paralympic Games Volunteer Program: Policy and Guidelines, New South Wales: Premiers Department, October 13.

Siedentop, D. (ed.) (1994): Sport Education: Quality Physical Education through Positive Sport Experiences. Leeds, UK.

World Volunteer Web (2005): Games to strengthen global recognition of volunteerism: UNV head, http://newsletter.worldvolunteerweb.org/e_article000424415.cfm?x= b5bnMk5,b2G2B D8G (accessed on July).

Volunteers Sochi. http://vol.sochi2014.com/en/ Downloaded September 20, 2013. 